Article

\title{
Sustaining Suburbia through New Urbanism: Toward Growing, Green, and Just Suburbs?
}

\author{
Dan Trudeau \\ Geography Department, Macalester College, Saint Paul, MN 55105, USA; E-Mail: trudeau@macalester.edu
}

Submitted: 29 June 2018 | Accepted: 3 September 2018 | Published: 30 October 2018

\begin{abstract}
This article examines the governance dynamics surrounding the development of sustainable neighborhoods in United States metropolitan contexts characterized as suburban sprawl. Drawing on original case study research of three distinct applications of New Urbanism design principles, the article argues for understanding the relative power of municipal authorities to incorporate social justice imperatives into the practice of sustainable development in suburban contexts. Moreover, key to prioritizing social imperatives is the way in which development processes respond to the "suburban ideal", which is a view of suburbs as an exclusive bourgeois utopia that constrains the ability to connect so-called sustainable development with social justice. Case study research shows how deference to the suburban ideal limits sustainable development to embracing growth and greening interests only and peripheralizing or denying social justice. The article discusses how sustainable development endeavors can address such constraints in the effort to create alternatives to suburban sprawl that integrate the pursuit of social justice with environmental protection and economic growth.
\end{abstract}

\section{Keywords}

New Urbanism; social justice; suburban ideal; suburbs; sustainable development

\section{Issue}

This article is part of the issue "Urban Planning and the Suburbs: Solutions for Sustainability from the Edges", edited by Markus Moos (University of Waterloo, Canada).

(C) 2018 by the author; licensee Cogitatio (Lisbon, Portugal). This article is licensed under a Creative Commons Attribution 4.0 International License (CC BY).

\section{Introduction}

American suburbs are the posterchildren of unsustainability. So goes the common perception of such places. The End of Suburbia (Greene, Silverthorn, Zwicker, \& Electric Wallpaper Company, 2004), a film about peak oil, captures this view well. It casts post-World War II suburban sprawl as the ultimate expression of an extractive system that cannot continue indefinitely. Overburdened by an insatiable demand for oil and stressed by a way of life that is alienating people from nature and community, End of Suburbia predicts the collapse of suburban lifestyles and the decline of suburban places. Against this current of thought, there are a variety of efforts to promote more sustainable environments through innovative development strategies in U.S. suburbs. Acknowledging this promotes a reckoning of the narrative that casts suburbs as unsustainable. Moreover, studying the actually-existing practices pro- moting sustainability in suburban contexts offers crucial insight into the progress-and remaining challenges-of sustainable development.

In this article I begin to investigate strategies for promoting sustainability in contexts of the U.S. that are dominated by suburban sprawl. My investigation is part of a larger project examining the implementation of $\mathrm{New}$ Urbanism, an urban design movement promoting compact, pedestrian-oriented, and mixed-use development. Drawing on case study research of three New Urbanist projects, I trace efforts to promote sustainability in suburban contexts in order to inquire about what can be expected from this movement's efforts to promote sustainable development. Results of my inquiry offer a picture of what a "made in the suburbs" strategy for sustainability looks like. This picture is framed by a view that sees sustainability as an effort to simultaneously advance economic growth, environmental protection, and social justice. The case studies confirm some of the ex- 
tant critiques of New Urbanism as a movement that ultimately fails to advance sustainability. This occurs, I argue, because developers and city officials mobilize New Urbanism to wrap a green veneer around development that ultimately reproduces the "suburban ideal" of access to middle-class community, property, and nature. At the same time, incorporating social justice into sustainable development in the suburbs is possible. Drawing on lessons learned from the case studies, I argue that seeing the relative power of municipal authorities to frame social justice concerns as a necessary part of sustainable development improves our ability to understand when and how New Urbanism can be used to promote growing, green, and just suburbs. Furthermore, a key part of municipal authorities' ability to promote social justice, I argue, hinges on mobilizing a vision of sustainable development that displaces the suburban ideal. In advancing this argument, I first define its key terms: the suburban ideal, sustainability, and suburbs.

The suburban ideal refers to a geographic imaginary of a place that is designed for the enactment of class privilege in a setting insulated from the textures of city life. This term draws on Teaford's work (1997, p. 9), which describes how the U.S. suburban ideal has been reinforced through advertising, which has persistently defined suburbia as "a residential environment where nature and the best people mingled to the benefit of anyone fortunate enough to purchase a homesite". Kotkin (2007) argues that the popular appeal of the suburban ideal in the U.S. has, for decades, sparked growth at the metropolitan periphery in the form of low-density, automobileoriented built environments. Hayden (2003) traces the emergence, change, and stability of the suburban ideal through the history of suburbanization in the U.S., underscoring how suburban sprawl is generated precisely because people see peripheral suburban places as locations where individuals ought to go to realize dreams of property ownership, access to nature, and community involvement. Fishman (1987) further clarifies that such dreaming is particular to middle- and upper-class interests and practically elusive, despite its widespread appeal. However, some have claimed that there are ways to promote economic growth, environmental protection, and social justice through New Urbanism (e.g., Farr, 2008; Kim \& Larsen, 2017), which hold promise for promoting sustainability in suburbs more generally.

Sustainability is a term fraught with ambiguity. The Bruntland Report (World Commission on Environment and Development, 1987) introduced "sustainability" to highlight the ways that economic, social, and environmental systems are interlinked, bringing awareness to the future effects of contemporary action. Bruntland also posited "sustainable development" as an on-the-ground endeavor to create settlements that move toward sustainability. Discourse around sustainable development has drifted from this specific meaning. Popular use of the term has led to a focus on environmental concerns. Commonsense usage simplifies it to mean an activity that can be continued indefinitely. Efforts to appropriate sustainability for radical change have nevertheless emerged in the past decade (e.g., Agyeman, 2013). Toward that end, I follow Dale and Newman's (2009, p. 670) conceptualization of sustainable development as a project to reconcile three imperatives:

(i) the ecological imperative to live within global biophysical carrying capacity and maintain biodiversity; (ii) the social imperative to ensure the development of democratic systems of governance to effectively propagate and sustain the values that people wish to live by; and (iii) the economic imperative to ensure that basic needs are met worldwide.

This article thus relates discussion of solutions for sustainability in suburbs to a specific concern for generating settlements that promote social justice, economic prosperity, and adhere to the ecological imperative of sustainability. Following Campbell's (1996) conceptualization of sustainable development, this means shaping development such that it simultaneously contributes to economic growth, is accessible to groups across the continuum of social differentiation, and impacts the natural environment in ways that can be supported indefinitely.

In this article, I focus on efforts to promote sustainability in contexts that are characteristic of suburban sprawl. In defining "suburban sprawl", I follow Forsyth's (2012, p. 273) strategy of describing suburban places along three dimensions: physical qualities, including situation and built environment; functional attributes, such as how inhabitants travel in and through them and the range of activities they support; and sociocultural character concerning demographics, "level of exclusivity, and cultural heritage and tastes". The particular places I examine have each been built up in the postwar period, oriented around automobility, characterized by low-density, low-rise built environments, are planned to separate out residential landscapes from other land uses and segregate income groups by creating distinct areas for particular housing types. Such places are not without employment and consumption activities, but these are located in sites that are apart from residential landscapes.

\section{Sustainability and New Urbanism}

New Urbanism has a principal aim of changing built environments in order to foster a different way of life. The movement began as an environmental and aesthetic critique of suburban sprawl (White \& Ellis, 2007). It has since evolved to promote its design principles as a sustainability fix for problems associated with contemporary urbanization in the U.S. and beyond (Congress for the New Urbanism [CNU], 2008). The most tangible and widespread products of New Urbanism are neighborhood-level projects, which typify the movement, including the Stapleton Redevelopment Project, in Denver, and the Mueller Development, in Austin. These 
are also some of the most visible efforts of New Urbanism to promote sustainability, which ultimately take shape in a variety of ways, including suburban densification, such as Mizner Park in Boca Raton (Dunham-Jones \& Williamson, 2009), and conservation design communities, as seen in Prairie Crossing, Illinois (Zimmerman, 2001).

New Urbanism's turn toward sustainability appears in several moves. It is evident in efforts to frame New Urbanism as a strategy for generating Smart Growth, a broader effort in the U.S. to manage metropolitan growth such that investment is focused on the redevelopment of older areas and away from the periphery and generates denser forms of settlement (Knaap \& Talen, 2005). It is also apparent in CNU's partnership with the U.S. Green Building Council and the National Resource Defense Council to create the LEED-ND rating system (CNU, 2007). While these efforts are most obviously attuned to managing the tensions between environmental and economic imperatives of sustainability there has been ongoing, though tepid, interest to promote social equity through the movement. This has generated critiques about New Urbanism's asserted connection to the social imperatives of sustainability.

One of the longstanding critiques about New Urbanism's unsustainability is that it merely repackages suburban sprawl. Through his detailed critique of the Kentlands neighborhood in suburban Maryland, Marshall (2001) frames the broader movement as a weak attempt to alter suburban lifestyles. He argues that New Urbanism produces built environments where residents enjoy the pretense of urban places-denser settlement patterns, pedestrian-oriented streets, and interaction with neighbors-but still experience life in an exclusive bubble, insulated from social diversity and dependent on automobiles. This line of criticism sees that New Urbanism may change the look and feel of sprawl, but it does not change how it functions (Lehrer \& Milgrom, 1996). Other scholars build on this critique. Sweeney and Hanlon (2016) describe how built-out suburban municipalities facing fiscal decline are drawn to New Urbanism in order to intensify land use and attract new residents in an increasingly competitive metropolitan economy. Grant (2007) sees New Urbanism as generating neighborhoods that are like gated communities: disconnected from the larger metropolis, but without the physical walls. Cabrera and Najarian's (2013) examination of social interaction in Civano, Arizona acknowledges that New Urbanist neighborhood populations may be socially diverse, yet this has not translated into interaction amongst people from different age, sex, and income groups. In their analysis of Seaside, Florida, AlHindi and Staddon (1997) discuss how the project's antebellum nostalgia constructs the place as celebrating white bourgeois subjectivities, which alienates others and hamstrings the movement's aspiration for fostering social diversity. Arguments about New Urbanism's exclusivity are further developed by González and Lejano (2009), who see New Urbanism as a vehicle for normaliz- ing white middle-class aesthetics in the redevelopment and gentrification of downtown Santa Ana. This point is extended in Markley's (2018) study of suburban Atlanta, where he finds that New Urbanism projects are sited in gentrifying neighborhoods where Latinx populations are decreasing and white populations are concomitantly on the rise. Zimmerman's (2001, p. 251) study of the conservation community at Prairie Crossing, Illinois, encapsulates a number of these critiques about New Urbanism as ultimately recreating sprawl:

Behind the façade of sustainable development, Prairie Crossing is in fact a resurrection of, and defense of, the suburban ideal-the exclusive residential retreat physically removed and insulated from the city, that, when viewed within its broader-metropolitan context, should be understood as contributing to sprawl and its concomitant environmental harm.

These critiques cast New Urbanism as a movement that adds a green veneer to business-as-usual approaches to developing socially exclusive places.

But how far can these specific examples be applied to the broader movement? New Urbanism may appear as a single coherent movement, yet it is highly differentiated in practice. Recent scholarship has shown how there are multiple New Urbanisms (Grant, 2006; Moore, 2010; Trudeau, 2013). Such work underscores McCann's (1995) argument that the discourse of New Urbanism is selectively and strategically deployed in ways that relate particular interests that resonate in time and place. Consequently, the time is now right for closer examination of the ways New Urbanism is deployed to advance sustainable development in U.S. suburban contexts.

\section{Developing Differently? Analyzing Sustainability in Suburbia}

In light of extant variation of New Urbanism in practice, this article asks: how far can the critiques about New Urbanism as generating sprawl and failing to advance sustainability be applied? What insights for advancing sustainable suburban development generally can be realized from studying decidedly different instances of New Urbanism? Engaging these questions provides a way to think critically about what can be expected from New Urbanism and its avowed interest in sustainability as it is deployed on the suburban frontier. In this inquiry, I draw on research about the processes that generated three different types of New Urbanist settlements in contexts defined by suburban sprawl. My focus here is to examine the governance dynamics surrounding what I have elsewhere termed "development communities" (Trudeau, 2017), which use, to varying degrees, the tools, ideas, and geographic imaginaries associated with New Urbanism to generate sustainable development.

Development communities refer to the constellation of actors involved in development projects. Each 
is distinct, but generally speaking, these communities are composed of land developers, municipal authorities (e.g., elected officials, planners), consultants, financiers, and residents, among other actors, who define the goals of a project and shape its implementation. Close examination of how development communities define sustainability, envision projects, and commit resources to its implementation yields valuable insight into the processes that generate sustainable development. Following Yin (2014), case study research is particularly well suited to generate new understanding about how processes operate.

The three case studies I discuss in this article draw on a larger research project focused on processes driving the creation of nine neighborhood-level New Urbanist projects distributed across three metropolitan areas. Here, I examine case studies from just two areas, Denver and Minneapolis-St. Paul, in order to illustrate three distinct processes generating sustainable development amidst suburban sprawl. I profile how the development community associated with each case operated to produce a distinct built environment-green single-family neighborhoods, new suburban downtowns, and socially inclusive neighborhoods-which is explicitly connected with New Urbanism and framed as either Smart Growth or contributing to sustainability, or both. In total, I conducted 16 semi-structured interviews with actors in each development community, collected news stories and gray literature on each project, and gathered official documents, such as draft plans and land use ordinances, where available. Reflecting on this data, I discuss each case in order to theorize how leadership arrangements in each development community matters for the depth of engagement with all three logics of sustainable development (i.e., economic, environmental, and social). I follow Stone's (1993) description of leadership in urban governance as the ability to generate a vision for change and mobilize others to provide material and discursive support. To be sure, this is not an exhaustive account of the processes through which suburban sustainable development manifest. Nevertheless, analysis offers insight into the ways that development communities approach sustainability in suburban contexts through application of New Urbanism principles to neighborhood-level projects and the successes and continuing challenges this entails.

I analyze each case using a framework that considers movement towards sustainability across different facets of suburbia, as described by Forsyth (2012): physical, functional, and sociocultural. Campbell's articulation of "the planner's triangle" helpfully frames sustainable development as the convergence of interests promoting environmental protection, economic growth, and social equity. While the planner's triangle correctly conceptualizes sustainability as the combination of these distinct interests, it still presents these as inherently divergent and posing fundamental conflicts. In Campbell's (1996, p. 299) account, "business resists the regulation of its exploitation of nature, but at the same time needs regulation to conserve those resources for present and future demands". This tension between environmental and economic sustainability creates a "resource conflict", the likes of which must ultimately be resolved through conflict management and trade-offs. Campbell acknowledges that there is, to a degree, inherent complementarity around the different points of interest in the planner's triangle. However, he frames sustainable development as the hard work of gaining compromise among the conflicts that develop between these interests.

Others have pushed back against the trade-off thinking inherent in Campbell's approach to sustainable development. Agyeman's (2013) "just sustainabilities", for instance, shows how gains in environmental protection that lighten developments' ecological footprint are actually achieved as a matter of promoting income equality. Agyeman posits achieving sustainability as resulting from the synthesis of the economic, environmental, and social justice interests. Dale and Newman (2009) frame such a view as fostering reconciliation, or the integration, of distinct logics. Following Dale and Newman, I pay particular attention to the ways in which the social imperative of sustainability can be bedeviled by polarizing concerns. As Vallance, Perkins and Dixon (2011) show, "social sustainability" must tend to concerns for equity and inclusion, on the one hand, and interests in community continuity and the continuation of established values and ways of life in a place, on the other. In the following sections, I discuss how relative positioning of municipal authorities in development communities matter to on-theground practices of sustainable development in suburban contexts.

\subsection{Green Single-Family Neighborhoods}

Bradburn, in suburban Denver, illustrates how a developer can wield New Urbanism to re-package the suburban status quo as a green single-family neighborhood that protects property values and offers affluent residents access to environmental amenities. Located in Westminster, Colorado, Bradburn is a 125 -acre Traditional Neighborhood Design (TND) neighborhood that breaks from established development patterns in this second-ring suburb. As one of New Urbanism's signature forms, TND is an interpretation of early 20th century urban villages that envisions a compact and walkable neighborhood of single-family homes oriented around a commercial core or main street and includes low-rise multifamily housing. New Urbanist luminaries Andres Duany and Elizabeth Plater-Zyberk (1991) framed this approach as "the second coming of the American small town". Bradburn's adherence to the TND concept is evident in its street grid system, sidewalks, orientation around a main street, and incorporation of schools, churches, and retail businesses into the development. This form interrupts the uniformity of post-war suburban subdivisions and strip malls that predominate in Westminster. Opened in 2003, Bradburn conforms to the low-rise landscape in 
Westminster, but its compact form-achieved through smaller lot sizes, short setbacks from the street, accessory dwelling units, and incorporation of multi-family buildings - makes it noticeably denser.

Living in Bradburn comes at a premium, however. Single-family homes there were produced by custom builders and offered at prices affordable to households earning at least $100 \%$ of the area median income (AMI). According to the developer's project manager for Bradburn (personal communication, May 15, 2013), some of the multi-family units were offered initially at prices that were affordable to households at $70 \% \mathrm{AMI}$, but there are no measures to keep this pricing in place. Rental housing in Bradburn is likewise marketed as offering luxury accommodation, adding to its exclusive image. One of the reasons why residents may be willing to pay this premium is because of Bradburn's proximity to the picturesque grassy foothill landscape in the open space maintained by the city, which border half of Bradburn's perimeter. Orientation toward the natural environment is mirrored in the green building standards of all residential structures in Bradburn and the solar panels that wreathe many roofs. Pedestrian-oriented neighborhood design, exposure to open space, and conspicuous use of green building help confer Bradburn with a distinctive character, which was part of the original plan for the project (Collins, 2007).

Bradburn took shape through the pursuit of two distinct, yet complementary land development agendas. The City of Westminster was interested in creating denser subdivisions to maximize development of its remaining land (City of Westminster, 2008). Westminster implemented a growth management program in 1978, which has provided considerable leverage over development. According to the Westminster planning manager (personal communication, May 21, 2013), planners had realized by the mid-1990s that denser development would help the city continue its growth as the city was running out of developable land. In 1997, Continuum Partners, a Denver-based developer, saw in Westminster an opportunity to demonstrate its capacity to build TNDs and contribute to the Smart Growth movement taking shape at that time in the Denver region (Continuum president, personal communication, May 16, 2013). The TND ultimately fit well with the city's land development plan, yet it was not legally permitted. In response, Continuum worked with Duany and Plater-Zyberk to generate a TND ordinance for Westminster (City of Westminster, 2006), which would ultimately authorize the paradigm shift entailed in Bradburn.

Changing land use law in the city was only part of the challenge. The proposed street system raised concern that trash haulers and fire trucks would be unable to move their vehicles through the development. Continuum responded by bringing city officials, planners, and public works managers to visit an established suburban TND in the Kentlands, Maryland (Westminster planning manager, personal communication, May $21,2013)$. This helped establish a proof of concept, yet uncertainty still lingered. Ultimately, Westminster officials and planners were encouraged by Continuum's effort to make Bradburn an exemplar of New Urbanism and Smart Growth, which promised to raise Westminster's profile in the wider region as a place where sustainable development takes shape (former Westminster planning manager, personal communication, May 13, 2013). In addition to working with experts in Duany and PlaterZyberk, Continuum set lofty-and expensive-standards in the architectural pattern book generated for Bradburn. To complement this, the City supported Continuum's effort to create a brand identity for Bradburn (Continuum project manager, personal communication, May 15, 2013). The subdivision has street signs that are a different color from others in the city and feature a unique font and symbol that appear on signage throughout the project. As Continuum's project manager (personal communication, May 15, 2013) for Bradburn explained, the incorporation of green building practices and solar panels was part of this strategy to mark Bradburn as a highend development that was a clear "departure from suburban sprawl and ecologically responsible in its land plan". This strategy helped create Bradburn as a place wherein residency would confer status as a participant in fostering green development.

Green single-family neighborhoods like Bradburn represent a visible departure from automobile-oriented landscapes that predominate in the postwar suburban sprawl of Westminster. The story of Bradburn's creation illustrates how challenging it can be to make such a change because underneath the surface of how the built environment appears is a network of social and governmental institutions that normalize suburban sprawl. Continuum partners led the way in mobilizing the development community of Bradburn and the city inflected this charge with equal parts encouragement for a focus on social distinction through design and enforcement of standards for services and infrastructure that ultimately integrate Bradburn into the wider city. On this point, the experience of building Bradburn did impact such institutions in Westminster. The TND ordinance Bradburn introduced was incorporated into the City of Westminster's (2008) comprehensive plan. Moreover, the residences and businesses filled quickly, signaling Bradburn's market appeal. Yet, Bradburn is likely attractive because it repackages the suburban ideal, not because it offers an alternative to it. Green single-family neighborhoods such as Bradburn are rightly critiqued as limited or weakly supporting sustainability, because the natural environment that is conserved through such development is ultimately framed as an amenity for residents and a device that supports property values and exclusivity (Lehrer \& Milgrom, 1996; Zimmerman, 2001).

\subsection{New Suburban Downtowns}

Belmar, also in suburban Denver, shows how developers leverage financial and legal support from municipal 
authorities and use the ideas and imaginaries of New Urbanism to provide a sustainability fix for cities experiencing fiscal stress with little remaining undeveloped land. Located in Lakewood, Colorado, Belmar is built on the site of the Villa Italia Mall and is one of the featured cases of "suburban retrofit" profiled by Dunham-Jones and Williamson (2009). The mall was built in 1966, a few years before several scattered nodes of residential and commercial development incorporated as the City of Lakewood. These areas incorporated pre-emptively to avoid exposure to a court-ordered desegregation busing program affecting nearby Denver. As municipal incorporation connected these nodes, the Villa Italia Mall emerged as Lakewood's third place. More than just a shopping center, the mall served for decades as a social hub, hosting events like high school prom and wedding receptions and providing a meeting place for family dining and senior citizen walking groups. The mall started to decline both aesthetically and financially in the 1990s. In 1994 , it had contributed $\$ 3.2$ million, or $11.5 \%$ of the city's sales tax income, which had dropped precipitously by 2001 to $\$ 1.2$ million, or $3.1 \%$ of the city's tax income (Able, 2004). City officials consequently began to frame it as an economic liability and searched for an alternative (Swope, 2002).

Convinced that the beloved auto-centered mall was the "wrong model for the future", city officials sought to frame the development of a new downtown with retail, commercial, and residential land uses as a way for Lakewood to attract new residents and capital and compete in the broader economy of the Denver region (former Lakewood planning manager, personal communication, May 20, 2013). Anticipating Sweeney and Hanlon's (2016) observation that new downtowns are an entrepreneurial strategy for suburban municipalities facing fiscal uncertainty, Lakewood's mayor, Steve Burkholder (personal communication, May 14, 2013), framed the question of developing Belmar to the public in unequivocal terms: "We could either be [a] backwater, first ring suburb, or we can choose to jump into the twenty-first century, and we started to share this New Urbanist vision of...mixed-use development". Indeed, Burkholder was elected to address the mall's decline, which he pursued by replacing it with a dense, walkable, and green downtown district.

Inspired by attending a CNU meeting, Lakewood officials worked with Continuum Partners to apply New Urbanist design principles in designing Belmar, which was opened in 2004. Continuum initially turned down Lakewood's proposal, but the mayor's persistence led Continuum's leadership to reconsider (Continuum project manager, personal communication, May 14, 2013). Moreover, the city had labored to prepare the way for a sweeping change as the Burkholder administration created a redevelopment authority to exercise eminent domain, assemble land, and finance redevelopment through a TIF district. With such support behind them, Continuum worked to connect its vision for a new downtown with residents' and business leaders' concern with the redevelopment of the Villa Italia Mall. The developer engaged these interests through a communityadvisory group, which met for over a year and worked to respond specifically to concerns about density and yearning for the communal spaces that once existed in the mall (Continuum president, personal communication, May 16, 2013). Reflecting on the function of the advisory group, Continuum's project manager for Belmar (personal communication, May 14, 2013) explained:

By the time that process had unfolded over the course of a year...everybody was pretty sure that they came up with the idea [for Belmar as a mixed-use development] and that it had always been their idea and that we were just carrying it out....But in truth, it was our idea-that's why we came there and we knew that's what it needed, but we didn't start there.

The developer thus leveraged public engagement to legitimate a development plan that they believed would provide a substantial return on investment over the long-term.

This process culminated in a design for the 103-acre district that introduced a fine-mesh street grid that focused density at the center, incorporated public spaces throughout, and used green building practices. Belmar's center features buildings that mix street-level retail and restaurants with commercial office space above. Buildings with street-level retail and luxury apartments and condominiums surround the center. Several plazas, promenades, and green spaces connect additional apartment buildings and row houses, which are flanked by big-box retail buildings at the district's perimeter, which are defined by highways. Continuum installed an array of solar panels that generate 2.3 megawatts of energy and constructed LEED certified buildings. Most residential buildings in Belmar meet national or local green certification practices. These elements helped substantiate the commitment to make Belmar a place that would attract interest and investment from environmentally conscious companies, consumers, and residents (former Lakewood planning manager, personal communication, May 20, 2013).

The development of Belmar both represents a departure from postwar suburban patterns and reinforces them. Belmar introduced a new form to Lakewood's built environment, creating a walkable, denser landscape that combines living, consumption, working, and leisure activities in a single space. Beyond the physical change, Belmar has culminated in a thriving mixed-use development that enables a novel lifestyle in suburban Lakewood. Its success as a leisure and shopping destination as well as its commitment to renewable energy generation has given Lakewood a new story to tell about its identity and serves as an exemplar of sustainable suburban development in the wider metropolitan region (Briggs, 2014). Yet, while walking is the most practical 
way to move around Belmar. Residents and visitors alike continue to rely on automobiles. Belmar is easily a mile away from the nearest public transit station and a shuttle connects the two, yet its once-an-hour schedule between 11 am and 7 pm ultimately does not offer a compelling alternative to the personal automobile.

The ideal of suburbia as an exclusive haven for the well-off thus persists in Belmar. The year-long conversation with the community advisory group helped ease aversion to a denser landscape and create a story that connects the memory of Villa Italia Mall as a social hub with the design and use of public space in Belmar. For instance, Belmar hosts an annual Italian festival and regularly offers free outdoor concerts in the summer months. For as much as this process helped to generate sustainability of community, it also protected the centrality of the suburban ideal. Created as a business improvement district, the public spaces of Belmar are patrolled by a private security force. This ensures recreational uses do not interfere with the district's orientation toward work and consumption. Moreover, planners prioritized the protection of property values in Belmar's housing market when they declined a proposal to site subsidized senior housing in the district out of concern that it would detract from the district's image (Continuum project manager, personal communication, May 14, 2013). While the district is a visible symbol of environmental sustainability, it nonetheless reproduces elements of the suburban ideal-such as an emphasis on exclusivity, social distinction, and property-that made the Villa Italia Mall popular.

\subsection{Socially Inclusive Development}

The City of Chaska's efforts to develop Clover Ridge provides insight into the ways in which social equity, in the form of affordable housing, has been integrated into a TND promoting environmental sustainability in a suburb. This case is instructive because New Urbanism's Charter explicitly calls for development that "bring[s] people of diverse ages, races, and incomes into daily interaction" (CNU, 1996). However, scholarship shows this aspiration is frequently ignored or unfulfilled. Less than half of New Urbanist developments in the U.S. include housing that is affordable to people with low- or very low-incomes (Johnson \& Talen, 2008). Controlling for federal housing subsidy programs, that proportion is even lower (Talen, 2010). However, there are some projects that advance social inclusion (Kim \& Larsen, 2017). The case of Clover Ridge illustrates how development communities led by municipal authorities that prioritize social inclusion are able to integrate this interest into the environmentallyfocused aspects of suburban development that the preceding case studies highlight.

Located in Chaska, Minnesota, Clover Ridge is at the urban-rural fringe of metropolitan Minneapolis-St. Paul. Chaska was initially settled in 1851, approximately 25 miles from Minneapolis. As Minneapolis-St. Paul ex- panded since 1945 , suburban sprawl inevitably encompassed small-town Chaska and in the past four decades, development there has repeated patterns that separate land uses and require automobiles for daily life. Highway improvements in the 2000s increased the accessibility of Chaska to the larger metropolitan area, which introduced increased demand for more development, including housing, in Chaska. Since the 1980s, Chaska's comprehensive plans have cited a need for "low- and moderate-income housing". Acknowledging this need, Chaska's planners sought to develop a project that would provide a way to propagate the city's small-town character in new development along the highway corridor and offer an alternative to the suburban sprawl defining existing development in Chaska and nearby municipalities (City of Chaska, n.d.). Like Lakewood and Westminster, Chaska was searching for a way to develop differently in order to distinguish itself from neighboring municipalities. Its strategy, however, is driven by a sentiment of rejecting "the suburban view of the world", explained Chaska's former mayor (personal communication, April $12,2013)$, and he went on to state that "the vision for Chaska was to be the best small-town in Minnesota". Chaska's planners turned to New Urbanism for realizing this vision because it offered a vehicle for Chaska to grow in ways that engaged interest in building affordable housing and connecting new growth with aspects of the City's small-town character found in its historic downtown. Chaska's City council supported this interest and provided assistance at key moments (Chaska planning director, personal communication, March 20, 2013).

Clover Ridge is shaped considerably by city government, though it recruited private developers to finance and build different elements of its plan. Built on a farm at the city's periphery, plans for 255-acre development in Clover Ridge emerged through planners' discussion with the land owners, who were looking to transition it to a more profitable use. Planners communicated a New Urbanist vision for the farmland's development and even arranged for the owners, city councilmembers, and design consultants to visit TNDs in Oregon and Alberta to demonstrate their feasibility and consider how it could apply in Chaska. Planners worked with the land owners to create a master plan for the project and contracted with local builders to execute it. Clover Ridge was ultimately built as four different sub-districts that offered different housing types and density all connected through an integrated pedestrian-oriented street system. The town center features apartment buildings, retail space, and a transit station. Other districts include row houses and single-family homes. An elementary school was built adjacent to the town center. Clover Ridge's approach amidst suburban sprawl helped it earn recognition as a model form of transit-oriented development in the region (Metropolitan Council, 2006). Clover Ridge is also oriented around a protected greenbelt where signage communicates the importance of land conservation for wildlife habitat. A focus on energy efficiency among 
some builders has also led the project to be identified as a "Minnesota Green Community" (Greater Minnesota Housing Fund, 2011).

City councilmembers, the mayor, and planners worked from the start to incorporate affordable housing. This effort ensured that $25 \%$ of Clover Ridge's 1001 housings units are affordable to people with incomes at or below $80 \% \mathrm{AMI}$ and distributed throughout all sub-districts (Trudeau \& Malloy, 2011). The city achieved this through three approaches. The city arranged to work with one of the builders because it could provide low-cost modular housing that was assembled into row houses, which was priced for households earning $60-70 \%$ AMI. Planners worked with a nonprofit housing developer to generate apartment buildings with units that are affordable to renters with very low-incomes, from below $30 \%$ to $60 \%$ AMI. Fourteen of the units are reserved for households that have experienced homelessness. The nonprofit developer also works with the county to operate supportive services to its renters. Finally, the city created a community land trust to generate ownership-based affordable housing for households earning $60-80 \%$ AMI. The latter two approaches stand to provide affordable housing for at least 20 years. Supporting this effort, the city also engaged in a public relations campaign to manage tensions that might surface in response to the construction of affordable housing. The planning director (personal communication, March 20, 2013) explained the approach:

You have to really be very strategic and [lay] the groundwork early with the politicians, but also the public. From the beginning, you start talking about the people who you're trying to provide housing for and talk about what we need: we need places for teachers and we need places for police officers, we need places for snowplow drivers-people who the community values.

And the former mayor (personal communication, April $12,2013)$ noted that city officials framed Clover Ridge as "sustaining the values of small-town community" in Chaska.

Clover Ridge demonstrates how socially inclusive development can impact the sociocultural aspect of suburbia. While development of Belmar and Bradburn each introduce compact, walkable, and mixed use built environments that depart from the physical form of suburban sprawl and its functions, neither upsets the sociocultural embrace of the suburban ideal. Indeed, the market success of each hinges to an extent on the ways the ostensible break with the norm actually works to serve interests that use suburban land development to mark cultural distinction and create boundaries in place that reference and perform social exclusivity. Belmar, in particular, illustrates the tension that can emerge between two elements of the social imperative of sustainability: sustainability of community and social justice. In contrast, such tension is resolved in the development of Clover
Ridge. Chaska's city council and planning department led the process of visioning and planning and prioritized the development of affordable housing in Clover Ridge. The mayor at the time worked with the city council and planners to gather the necessary resources to finance affordable housing and simultaneously disseminated a message that creating a place with housing options for different segment of the population promotes core values of Chaska's community. Pitched as offering something different from the suburban ideal, city officials saw in Clover Ridge an opportunity to move away from the automobile-oriented sprawl that had developed in other parts of Chaska and cultivate small-town character that officials already recognize as a core part of the city's identity (City of Chaska, 2012). City officials and planners ultimately applied New Urbanism principles because they helped make a compelling link between community and social equity, which then affected the built environment in the process.

\section{Conclusion: Sustaining Suburbia or Advancing Suburban Sustainability?}

End of Suburbia predicts the suburbs' collapse based on the scarcity of inputs for an automobile-centered economy. This narrative incorrectly presumes that U.S. suburbs are a technological phenomenon. Rather, as scholars like Hayden (2003) have argued, suburbs are a remarkably resilient cultural formation that adapt to changing circumstances. Indeed, land developers and their allies extol suburbs' proximity to nature, protected property, and homogeneous community. Pursuit of this suburban ideal has likewise adapted to-and partially appropriated-sustainable development. This article illustrates some of the ways such appropriation sustains suburbia and takes shape through use of New Urbanism design principles. At the same time, against tendencies that totalize the critiques of some New Urbanist communities (e.g., Marshall, 2001), I show that there are efforts to promote social justice through application of New Urbanism principles that also advance sustainability in the development of suburbs.

The cases of Belmar and Bradburn confirm longstanding criticisms concerning the ways New Urbanism is applied to effectively repackage suburban sprawl. Strategies promoting sustainable development through suburban densification or green neighborhoods, as illustrated in case studies of Belmar and Bradburn, respectively, show different ways development communities use New Urbanism to offer a sustainability fix for continuing profitmotivated business-as-usual development. Such strategies offer ways to generate change in both the physical and functional aspects of established suburban patterns. Nevertheless, they fall short in advancing a holistic view of sustainability as the integration of three logics of economic growth, environmental protection, and social justice. Taken together, these cases add to the critique that New Urbanism is deployed to sustain suburbia in two dis- 
tinct ways. On the one hand, we see that development communities in each case deliberately generate and execute plans that embrace the suburban ideal and use New Urbanism to create places that appear to work differently and move toward greater environmental protection, but ultimately support the profit motives of land developers. On the other hand, it is evident that suburban municipalities are attracted to and enable the sustainability fix that New Urbanism portends to offer precisely because of its emphasis on securing stable growth and lasting value through careful attention to physical planning. Whereas Sweeney and Hanlon (2016) show this at work in suburban densification projects like Belmar, the case of Bradburn shows the entrepreneurial attraction of New Urbanism also applies to suburban municipalities focused on green single-family neighborhood development. These projects exemplify the established critique that New Urbanism largely sustains the status quo of suburban development. The case of Clover Ridge suggests, however, that this critique does not apply to all efforts using New Urbanism to advance sustainable suburban development.

Sustainable development in Clover Ridge integrated social justice into the ecological and economic imperatives precisely because the development community prioritized it and sought an alternative to the suburban ideal. In contrast to the configuration of the development communities operating in Belmar and Bradburn, the municipal authority-led effort to plan and build Clover Ridge enabled affordable housing for a range of income groups to be an integral part of its approach to sustainable development. Mayor, city council, and planning agencies succeeded to advance social justice, economic growth, and greening agendas because they labored to find land developers and builders that would support this end and cultivated a narrative that developing Clover Ridge as a socially inclusive place sustained community norms and identity. If not for this narrative, exclusionary interests could align development with the suburban ideal, as unfolded in Belmar. If not for the leadership of municipal actors, profit-driven interests could dominate the discussion of how best to grow the city, as exemplified in Bradburn.

Clover Ridge is just one instance of sustainable development in the suburbs, yet it speaks to a broader point that social imperatives can indeed be integrated with the ecological and economic imperatives of sustainability. Clover Ridge's experience emphasizes that promoting sustainable development that integrates social, ecological, and economic logics is accomplished by leadership that coordinates different actors in a development community and brings the necessary resources to support action. Key to this is planning from the start about how to connect justice with sustainability of community. Officials turned to Chaska's historic small-town identity to link equity with sustainability of community. Moreover, the city's message that affordable housing needs to be provided to "people who our community values" is problematic to say the least as it refracts complex relationships of community solely through an economic lens, which undoubtedly leaves out populations who need housing and ought to be a part of a vision promoting sustainability. This caveat notwithstanding, Clover Ridge's approach is surely not the only path toward the integration of social, ecological, and economic imperatives and further research exploring the multiple ways this can occur-and how these relate to the suburban idealwill advance our understanding of "made in the suburbs" strategies for sustainability.

\section{Acknowledgments}

I am indebted to the people who participated in the research project, sharing their time, insights and recollections. Their generosity and interest helped make this work possible. Thanks also to the anonymous reviewers who provided constructive feedback on the article. Finally, I appreciate Professor Markus Moos' efforts to organize and edit the special issue in which this article appears.

\section{Conflict of Interests}

The author declares no conflict of interests.

\section{References}

Able, C. (2004, May 15). Lakewood unveils new downtown. Rocky Mountain News.

Agyeman, J. (2013). Introducing just sustainabilities: Policy, planning, and practice. New York, NY: Zed Books.

Al-Hindi, K., \& Staddon, C. (1997). The hidden histories and geographies of neotraditional town planning: The case of Seaside, Florida. Environment and Planning D: Society and Space, 15(3), 349-72.

Briggs, A. (2014, May 6). Ten years later, Belmar exceeds expectations for Lakewood growth, identity. The Denver Post. Retrieved from www.denverpost.com/2014 /05/06/10-years-later-belmar-exceeds-expectationsfor-lakewood-growth-identity

Cabrera, J., \& Najarian, J. (2013). Can New Urbanism create diverse communities? Journal of Planning Education and Research, 33(4), 427-441.

Campbell, S. (1996). Green cities, growing cities, just cities: Urban planning and the contradictions of sustainable development. Journal of the American Planning Association, 62(3), 296-312.

City of Chaska. (n.d.). 2030 Comprehensive plan, chapter 4: Land use. Chaska, MN: City Hall. Retrieved from www.chaskamn.com/166/2030-Comprehensive-Plan

City of Chaska. (2012). Southwest growth and development plan. Chaska, MN: Hoisington Koegler Group Inc. Retrieved from www.chaskamn.com/Document Center/View/486/Southwest-Growth-and-Develop ment-Plan?bidld=

City of Westminster. (2006). Design guidelines for tradi- 
tional mixed use neighborhood developments. Westminster, CO: City Council. Retrieved from www.city ofwestminster.us/Portals/1/Documents/Government \%20-\%20Documents/Departments/Community\%20 Development/Planning/Traditional\%20Mixed-Use\% 20Neighborhood\%20Developments.pdf

City of Westminster. (2008). Comprehensive Land Use Plan, 2004. City of Westminster, CO: City Council.

Collins, T. (2007, June 1). McStain Homes at Bradburn Village: Solar-electric homes raise the bar on energyefficiency. Boulder Daily Camera.

Congress for the New Urbanism. (1996). Charter of the New Urbanism. Washington, DC: CNU. Retrieved from http://www.cnu.org/charter

Congress for the New Urbanism. (2007). Pilot version: LEED for neighborhood development rating system. Washington, DC: CNU, US Green Building Council, National Resource Defense Council. Retrieved from www.cnu.org/sites/default/files/LEED-ND-PROG.pdf

Congress for the New Urbanism. (2008). Canons of sustainable architecture and urbanism: A companion to the charter of the new urbanism. Washington, DC: CNU. Retrieved from www.cnu.org/charternew-urbanism/canons-sustainable-architecture-andurbanism

Dale, A., \& Newman, L. (2009). Sustainable development for some: Green urban development and affordability. Local Environment, 14(7), 669-681.

Duany, A., \& Plater-Zyberk, E. (1991). Towns and townmaking principles. New York, NY: Rizzoli.

Dunham-Jones, E., \& Williamson, J. (2009). Retrofitting suburbia: Urban design solutions for redesigning suburbs. Hoboken, NJ: Wiley.

Farr, D. (2008). Sustainable urbanism: Design with nature. Hoboken, NJ: Jon Wiley and Sons.

Fishman, R. (1987). Bourgeois utopias: The rise and fall of suburbia. New York, NY: Basic Books.

Forsyth, A. (2012). Defining suburbs. Journal of Planning Literature, 27(3), 270-281.

González, E., \& Lejano, R. (2009). New Urbanism and the barrio. Environment and Planning A, 41(12), 2946-2963.

Grant, J. (2006). Planning the good community: New Urbanism in planning and practice. London: Routledge.

Grant, J. (2007). Two sides of a coin? New Urbanism and gated communities. Housing Policy Debate, 18(3), 481-501.

Greater Minnesota Housing Fund. (2011). Clover Field marketplace. Chaska, MN: Minnesota Green Communities. Retrieved from www.fhfund.org/wp-content/ uploads/2016/03/CloverField.pdf

Greene, G., Silverthorn, B., Zwicker, B., \& Electric Wallpaper Company. (2004). End of suburbia: Oil depletion and the collapse of the American dream (Documentary).

Hayden, D. (2003). Building suburbia: Green Fields and urban growth, 1820-2000. New York, NY: Pantheon.

Johnson, J., \& Talen, E. (2008). Affordable housing in New
Urbanist communities: A survey of developers. Housing Policy Debate, 19(4), 583-613.

Kim, J., \& Larsen, K. (2017). Can New Urbanism infill development contribute to social sustainability? The case of Orlando, Florida. Urban Studies, 54(16), 3843-3862.

Knaap, G., \& Talen, E. (2005). New Urbanism and smart growth: A few words from the academy. International Regional Science Review, 28(2), 107-118.

Kotkin, L. (2007). The suburban archipelago (Working Paper no. 621). Philadelphia, PA: Samuel Zell and Robert Lurie Real Estate Center, The Wharton School, University of Pennsylvania.

Lehrer, U., \& Milgrom, R. (1996). New (Sub)urbanism: Countersprawl or repackaging the product. Capitalism Nature Socialism, 7(2),49-64.

Markley, S. (2018). Suburban gentrification? Examining the geographies of New Urbanism in Atlanta's inner suburbs. Urban Geography, 39(4), 606-630.

Marshall, A. (2001). How cities work: Suburbs, sprawl, and the roads not taken. Austin, TX: The University of Texas Press.

McCann, E. (1995). Neo-traditional developments: The anatomy of a new urban form. Urban Geography, 16(3), 210-233.

Metropolitan Council. (2006). Transit-oriented development project profile: Clover Ridge, Chaska. St. Paul, $\mathrm{MN}$ : The Metropolitan Council.

Moore, S. (2010). 'More Toronto, naturally' but 'too strange for Orangeville': De-universalizing new urbanism in Greater Toronto. Cities, 27(2), 103-113.

Stone, C. (1993). Urban regimes and the capacity to govern: A political economy approach. Journal of Urban Affairs, 15(1), 1-28.

Sweeney, G., \& Hanlon, B. (2016). From old suburb to post-suburb: The politics of retrofit in the inner suburb of Upper Arlington, Ohio. Journal of Urban Affairs, 39(2), 241-259.

Swope, C. (2002). After the mall: Suburbia discovers main street. Governing Magazine, 2002(October), 20-24.

Talen, E. (2010). Affordability in New Urbanist development: Principle, practice, and strategy. Journal of Urban Affairs, 32(4), 489-510.

Teaford, J. (1997). Post-suburbia: Government and politics in the edge cities. Baltimore, MD: Johns Hopkins University Press.

Trudeau, D. (2013). A typology of New Urbanism neighborhoods. Journal of Urbanism, 6(2), 113-138.

Trudeau, D. (2017). Patient capital and reframing value: Making New Urbanism just green enough. In W. Curran \& T. Hamilton (Eds.), Just green enough (pp. 227-238). New York, NY: Taylor \& Francis.

Trudeau, D., \& Malloy, P. (2011). Suburbs in disguise? Towards a geography of the New Urbanism. Urban Geography, 32(3), 424-447.

Vallance, S., Perkins, H., \& Dixon, J. (2011). What is social sustainability? A clarification of concepts. Geoforum, 42(3), 342-348. 
White, S., \& Ellis, C. (2007). Sustainability, the environment, and New Urbanism: An assessment and an agenda for research. Journal of Architecture and Planning Research, 24(2), 125-142.

World Commission on Environment and Development. (1987). Our common future. New York, NY: United Nations World Council on Economic Development.
Yin, R. (2014). Case study research: Design and methods (5th ed.). Thousand Oaks, CA: Sage.

Zimmerman, J. (2001). The 'nature' of urbanism on the New Urbanist frontier: Sustainable development, or defense of the suburban dream? Urban Geography, 22(3), 249-267.

\section{About the Author}

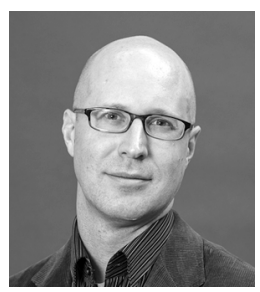

Dan Trudeau is a Professor in the Geography Department and Director of Urban Studies at Macalester College. His research interests include the political economy of public-private partnerships, the cultural politics of landscape production, and the social equity implications of sustainable urban design initiatives such as the New Urbanism. His scholarship has been published in journals including Cultural Geographies, Environment and Planning, GeoForum, Journal of Planning Education and Research, Political Geography, Urban Geography, and Urban Studies. 